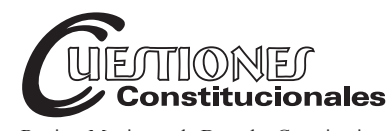

Revista Mexicana de Derecho Constitucional Núm. 42, enero-junio 2020

\title{
O direito constitucional ao esporte em perspectiva comparada*
}

\author{
Constitutional Right to Sport in a Compared Perspective
}

\begin{abstract}
Felipe CANAN**
Fernando Augusto STAREPRAVO***

RESUMO: a constitucionalização de um direito não significa sua garantia de fato, mas ao menos contribui para sua valorização social e geração de respaldo jurídico para sua reivindicação. Objetivou-se identificar o perfil geral da previsão constitucional do esporte e do direito ao esporte em perspectiva comparada, abrangendo suas características gerais, distribuição geoespacial e particularmente a dogmática do direito ao esporte. A pesquisa é descritiva documental, com abordagem quali-quantitativa. Investigou-se 75 constituições, das quais 49 preveem o esporte e 14 estabelecem o direito ao esporte, prevalentemente em países ibero-americanos e/ou do bloco de países de língua portuguesa. O termo esporte é comumente associado às expressões cultura física e/ou educação física. O núcleo essencial do direito ao esporte

ABSTRACT: the constitutionalization of a right does not mean its guarantee of fact, but at least it contributes to its social valorization and generation of legal support for its claim. The objective was to identify the general profile of the constitutional prediction of sport and the right to sport in a comparative perspective, covering its general characteristics, geospatial distribution and particularly the dogmatics of the right to sport. The research is descriptive and documentary, with a qualitative-quantitative approach. 75 constitutions were investigated, of which 49 forecast the sport and 14 establish the right to sport, predominantly in ibero-american or the block of portuguese-speaking countries. The term sport is commonly associated with expressions of physical culture or physical education.

* O presente trabalho contou com apoio financeiro de Bolsa CAPES-DS, nível doutorado, para sua realização.

** Doutor em Educação Física pela Universidade Estadual de Maringá, Brasil, professor da Universidade Estadual do Oeste do Paraná, Brasil. Correio:felipe.canan@gmail. com; ORCID: https://orcid.org/0000-0002-9450-778X.

*** Doutor em Educação Física pela Universidade Federal do Paraná, Brasil, professor da Universidade Estadual de Maringá,Brasil. Correio: fernando.starepravo@hotmail. com; ORCID: https://orcid.org/0000-0002-1655-998X.
\end{abstract}


encontra-se na liberdade de prática, na educação física escolar obrigatória e na gartuita de infraestrutura para prática.

Palavras-chave: esporte, cultura física, educação física, políticas públicas.
The essential core of the right to sport lies in freedom of practice, compulsory school physical education and free provision of infrastructure for practice.

Keywords: Sport, Physical Culture, Physical Education, Public Policy.

Resumo: I. Introdução. II. Procedimentos metodológicos. III. Resultados e discussão. IV. A dogmática do direito ao esporte em âmbito constitucional. V. Considerações finais.

VI. Referências.

\section{INTRODUÇÃO}

A constitucionalização de um direito não significa automaticamente sua garantia, mas contribui para sua valorização social e permite sua reivindicação em âmbito jurídico. ${ }^{1}$ Em outras palavras a constitucionalização confere um maior status a um direito, contribuindo para uma maior possibilidade de seu exercício e garantia do que haveria se não fosse elencado na Constituição.

Tendo em conta que muitos países, sobretudo aqueles em desenvolvimento, dadas suas precárias condições socioeconômicas não conseguem garantir satisfatoriamente muitos direitos, especialmente os de caráter social, a constitucionalização pode contribuir para que sejam entendidos e respaldados juridicamente sob uma perspectiva plausível, condizente com o contexto nacional. Ou seja, além da constitucionalização garantir status ao direito, pode contribuir para que seja formalizado sob uma perspectiva adequada à realidade do próprio país, a fim de permitir que haja condições fiáveis de ser garantido.

Nesse ponto é que reside a importância de uma análise pautada em perspectiva comparada, permitindo que verifique-se como os diferentes países pensam a respeito e tratam determinado tema ou direito, podendo contribuir para o aperfeiçoamento do ordenamento jurídico estatal interno. Além disso, tal exercício de análise permite identificar quais países apresentam entendi-

\footnotetext{
1 Melo Filho, Álvaro, "Desporto Constitucionalizado", Revista de Informação Legislativa, Brasília, ano 26, núm. 101, janeiro-março de 1989, p. 209.

Esta obra está bajo una Licencia Creative Commons

Atribución-NoComercial-SinDerivar 4.0 Internacional, IIJ-UNAM.
} 
mentos mais alinhavados entre si, possibilitando pensar-se na constituição de redes de discussão e construção coletiva. ${ }^{2}$

A análise do direito constitucional ao esporte em perspectiva comparada busca tentar compreender a lógica de previsão do esporte a partir do estudo e comparação das Constituições de diferentes países. Pode oferecer subsídios tanto para que se compreenda como cada Estado tem previsto o esporte e o direito ao esporte, quanto para apresentar modelos e alternativas para melhoria do texto constitucional e do exercício e garantia do direito em cada país. Em outros termos, no caso do direito ao esporte, a perspectiva comparada pode contribuir para elaboração/aperfeiçoamento de bases para políticas públicas que possam proporcionar seu exercício e garantia.

Entretanto, ainda que a temática do esporte seja abrangida por uma grande quantidade de Constituições na atualidade, nem sempre constou nos textos constitucionais. Como coloca Pachot Zambrana, ${ }^{3}$ apesar do esporte estar se consolidando desde a metade do século XX como uma das atividades sociais mais importantes, ainda não foi suficientemente compreendido sob o ponto de vista jurídico. No que diz respeito especificamente ao direito constitucional ao esporte, segundo o autor, a situação se agrava, havendo uma dívida do campo acadêmico em relação à sua dogmática ou desenvolvimento técnico-jurídico, que abrange seu estudo, entendimento e o esclarecimento de seus elementos constitutivos.

Esses elementos abrangem a natureza jurídica, a titularidade, o objeto, o núcleo essencial e os limites ao exercício do direito ao esporte. Resumidamente entende-se que a natureza jurídica é diretamente ligada às dimensões dos direitos fundamentais, sendo o fundamento jurídico encontrado na abstenção ou na ação estatal. A titularidade diz respeito àqueles que podem usufruir o direito e cobrar sua garantia dos destinatários, que são, consequentemente, aqueles que têm a obrigação de garantir o direito aos titulares. O objeto refere-se ao bem jurídico a ser protegido/garantido.

2 Maximiliano, Carlos, Hermenêutica e aplicação do direito, 20. ed., Rio de Janeiro, Forense, 2011, pp. 107-109.

3 Pachot Zambrana, Karel Luis, El derecho al deporte, la constitución y las normas de ordenación del deporte en Cuba, tesis (doctorado), La Habana, Universidad de Oriente, 2008, p. 14; Pachot Zambrana, Karel Luis, "El derecho constitucional al deporte en la doctrina y el derecho comparado", Cuestiones Constitucionales. Revista Mexicana de Derecho Constitucional, México, núm. 35, julio-diciembre de 2016, p. 131. 
O núcleo essencial trata-se do mínimo de proteção/garantia, que não pode ser obstaculizado e/ou deve ser obrigatoriamente garantido pelo Estado e demais destinatários. Os limites dizem respeito às possibilidades que o Estado ou outros destinatários têm de restringir a garantia do direito.

$\mathrm{Canan}^{4}$ acresce à compreensão dogmática do direito ao esporte a institucionalidade e a fundamentalidade. A primeira, como apresenta Toledo, ${ }^{5}$ diz respeito à concretude e objetividade da norma que estabelece o direito, ou seja, ao quanto a norma informa as possibilidades de materialização do direito por parte de seus operadores, minimizando a discricionariedade. A fundamentalidade, como ensina Sarlet, ${ }^{6}$ divide-se em formal e material. A formal relaciona-se basicamente à previsão constitucional de um direito dentre os direitos fundamentais ratificados na Constituição de um país, com aplicabilidade imediata e impossibilidade ou elevada complexidade para ser abolido. A fundamentalidade material encontra-se em todos os valores e direitos considerados mais importantes para promoção da dignidade da pessoa humana e garantia do sistema democrático.

$\mathrm{Na}$ literatura, de fato foram identificados poucos estudos que abordaram a questão dogmática do direito ao esporte, nenhum antes de Pachot Zambrana ${ }^{7}$ apontar a dívida do setor acadêmico. Apesar de Cazorla Prieto ${ }^{8}$ afigurar-se como expoente autor que influencia até a atualidade as discussões sobre as relações entre Estado e esporte, questões específicas sobre a dogmática do direito ao esporte, em termos de compreensão de alguns de seus elementos constitutivos parecem terem sido inauguradas por Pachot Zambrana. ${ }^{9}$ De-

4 Canan, Felipe, “Compreendendo o direito ao esporte no Brasil-constitucionalização, teleologia e dogmática, tese (doutorado em Educação Física), Maringá, Centro de Ciências da Saúde da Universidade Estadual de Maringá, 2018, p. 37.

5 Toledo, Renata Maria, As políticas públicas e o direito "social" ao esporte: uma análise a partir do estado do Paraná (1995-2010), tese (doutorado), Curitiba, Setor de Ciências Humanas, da Universidade Federal do Paraná, 2014, p. 20.

6 Sarlet, Ingo Wolfgang, A eficácia dos direitos fundamentais - uma teoria geral dos direitos fundamentais na perspectiva constitucional, 11. ed., Porto Alegre, Livraria do Advogado, 2012, p. 59.

7 Pachot Zambrana, Karel Luis, El derecho al deporte..., cit., trabalho completo.

8 Cazorla Prieto, Luis María, "Deporte y Estado", Revista Aranzadi de Deporte y Entretenimiento (Monografía), Cizur Menor, 2013, trabalho completo. A versão consultada para presente pesquisa data de uma reedição de 2013, mas o original da obra é de 1979.

9 Pachot Zambrana, Karel Luis, El derecho al deporte..., cit., trabalho completo. 
pois dele foram identificadas discussões com robustez aproximada também em Flores Fernández, ${ }^{10}$ Castilla ${ }^{11}$ e Canan. ${ }^{12}$

Porém, há de se destacar que o próprio esporte não figura há muito tempo nas preocupações jurídicas, especialmente em âmbito constitucional, daí também resultando no pouco interesse do campo acadêmico. Explica Pachot Zambrana ${ }^{13}$ que

...na medida em que evoluíram as concepções ideológicas, políticas e filosóficas sobre as quais se baseiam os diferentes modelos de Estado foram positivadas nos respectivos textos constitucionais as principais questões de interesse geral e particular das sociedades, entre as quais, as de conteúdo social tomaram uma transcendência vertiginosa.

Complementa o autor ${ }^{14}$ que na grande maioria dos ordenamentos jurídicos estatais contemporâneos, a Constituição do país trata-se da norma jurídica fundamental e fundamentadora da sociedade, que busca respectivamente traduzir e regular harmonicamente necessidades e anseios sociais. Dentro desses anseios e interesses encontra-se o esporte, mas ele só tem sido abrangido com alguma representatividade após o terço final do século XX.

Independentemente se Estados mais liberais (constitucionalismo social) ou mais socialistas (constitucionalismo socialista), esferas de âmbito so-

10 Flores Fernández, Zitlally, "El contenido esencial del derecho al deporte. Perspectiva constitucional en Latinoamerica", Lex Social. Revista Jurídica de los Derechos Sociales, Sevilla, vol. 4, núm. 2, julio-diciembre de 2014, trabalho completo; Flores Fernández, Zitlally, "El derecho al deporte en México", en Flores Fernández, Zitlally (coord.), El derecho deportivo desde una perspectiva comparada. Los casos de España, México, Argentina, Cuba, Brasil y Mozambique, México, Editorial Flores, 2015, trabalho completo; Flores Fernández, Zitlally, "La cultura física y la práctica del deporte en México. Un derecho social complejo", Cuestiones Constitucionales. Revista Mexicana de Derecho Constitucional, México, núm. 40, enero-junio de 2019, trabalho completo.

11 Castilla, Karlos, "El derecho humano a la práctica del deporte. Una propuesta desde y para la Constitución mexicana”, Fair Play. Revista de Filosofía, Ética y Derecho del Deporte, Barcelona, vol. 3, núm. 2, 2015, trabalho completo.

12 Canan, Felipe, op. cit., trabalho completo. As discussões do presente texto, inclusive são resultados parciais e ao mesmo tempo desdobramentos dos dados apresentados pelo autor em sua tese de doutorado.

13 Pachot Zambrana, Karel Luis, El derecho al deporte..., cit., p. 33.

14 Idem. 
cial como o esporte, pouco concebíveis antes do Estado de bem-estar social, passaram a ser objeto de atenção pública e de textos constitucionais. ${ }^{15}$

Castilla, ${ }^{16}$ Cazorla Prieto, ${ }^{17}$ Miranda $^{18}$ e Pachot Zambrana ${ }^{19}$ apontam que o esporte somente teria adquirido o status constitucional a partir da inserção de preocupações com novos direitos sociais nas Constituições, depois que necessidades básicas, tais como saúde e educação, já se encontrariam minimamente atendidas no período pós-Segunda Guerra Mundial. $\mathrm{Na}$ ótica dos autores o esporte teria sido constitucionalizado a partir de suas relações com a qualidade de vida.

Mais especificamente, Cazorla Prieto ${ }^{20}$ e Miranda, ${ }^{21}$ diferenciam a introdução do esporte em Constituições de países liberais/capitalistas e socialistas/comunistas. Nos primeiros, teria se dado em decorrência e consonância a um estágio de desenvolvimento qualitativo dos países, afigurado no conjunto de liberdades e direitos característicos do Estado bem-estar social. O esporte seria um dos fatores de desenvolvimento integral dos cidadãos, complementando saúde, educação, cultura e lazer. Nos países socialistas/comunistas o esporte teria sido incorporado nas Constituições também como um elemento relacionado ao desenvolvimento integral do cidadão, mas associado à ideia de preparação do indivíduo para defesa do Sistema ou Regime. Para os autores, assim como para Pachot Zambrana, ${ }^{22}$ ainda que por caminhos distintos, os diferentes modelos político-econômicos chegaram a tratamento constitucional semelhante do esporte.

$\mathrm{Na}$ origem da previsão constitucional do esporte, ainda que Cazorla Prieto $^{23}$ e Miranda ${ }^{24}$ apontem a Constituição da República Democrática da Alemanha de 1968 como a primeira a tratá-lo como tema específico, é possível se identificar antecedentes na Constituição de outros países, tais como Albânia (1947), Bulgária (1947), Paraguai (1967), Polônia (1952), Romênia (1965), Suíça (1874) e Uruguai (1967), que previam generica-

\footnotetext{
15 Idem.

16 Castilla, Karlos, op. cit., p. 108.

17 Cazorla Prieto, Luis María, op. cit., pp. 189-192.

18 Miranda, Martinho Neves, O direito no desporto, 2. ed., Rio de Janeiro, Lumen Juris, 2011, pp. 18-22.

19 Pachot Zambrana, Karel Luis, El derecho al deporte..., cit., pp. 14 e 36-42.

20 Cazorla Prieto, Luis María, op. cit., pp. 189-195.

21 Miranda, Martinho Neves, op. cit., pp. 12-18.

22 Pachot Zambrana, Karel Luis, El derecho al deporte..., cit., p. 33.

23 Cazorla Prieto, Luis María, op. cit., p. 192.

24 Miranda, Martinho Neves, op. cit., p. 13.

Esta obra está bajo una Licencia Creative Commons

Atribución-NoComercial-SinDerivar 4.0 Internacional, IIJ-UNAM.
} 
mente um dever do Estado frente ao desenvolvimento físico dos jovens e/ou dos cidadãos em geral, como também identificado por Pachot Zambrana. ${ }^{25}$

Sobre o direito ao esporte especificamente, o primeiro indício de uma tentativa de constitucionalização encontra-se no processo constituinte da Constituição mexicana de 1917 , que acabou não abarcando tal direito. ${ }^{26}$ Somente no ano de 1976 é que o esporte acabou sendo constitucionalizado como direito, em Cuba (24 de fevereiro) e Portugal (2 de abril). ${ }^{27}$ Pachot Zambrana $^{28}$ tece uma crítica à literatura, principalmente europeia, que comumente aponta a Constituição de Portugal como a primeira a reconhecer o direito ao esporte e ao mesmo tempo deprecia a Constituição cubana porque supostamente restringir-se-ia à previsão de um constitucionalismo socialista, inclusive desconsiderando sua previsão do direito ao esporte.

Tendo esse breve cenário acadêmico e histórico-social em conta, objetivou-se neste artigo identificar o perfil geral da previsão constitucional do esporte e do direito ao esporte em perspectiva comparada. Especificamente, busca-se compreender as características gerais das formas como o esporte é previsto nas Constituições de vários países, o perfil geoespacial das Constituições que preveem o esporte e o direito ao esporte e a forma como se configuram os elementos constitutivos do direito ao esporte no seio constitucional. Vale dizer, neste último caso, que busca-se traçar a dogmática do direito ao esporte a partir de uma análise sistemática das Constituições que o preveem. Com essa pesquisa objetiva-se avançar na literatura em relação ao estudo do direito ao esporte e suas formas de exercício e garantia.

\section{PROCEDIMENTOS METODOLÓGICOS}

Trata-se de uma pesquisa descritivo-exploratória de abordagem quali-quantitativa, pautada na análise de documentos. Pesquisas exploratórias ob-

\footnotetext{
25 Pachot Zambrana, Karel Luis, El derecho al deporte..., cit., p. 34.
}

26 Schmitt de Bem, Leonardo, "La constitucionalización del deporte", en Millán Garrido, Antonio y Cervantes Liñán, Luis (dirs.), Anuario Iberoamericano de Derecho Deportivo, Lima, ano 2, núm. 2011, 2014, p. 70; Flores Fernández, Zitlallty, "El contenido escencial...", cit., 2014, p. 110; Pachot Zambrana, Karel Luis, El derecho al deporte..., cit., 2008 , p. 33.

$27 \quad$ Ibidem, p. 37. 
jetivam gerar uma visão geral sobre determinado fenômeno ainda pouco explorado pela literatura. As descritivas buscam descrever características e estabelecer relações entre variáveis relacionadas a determinado fenômeno. Quando as pesquisas descritivas contribuem para que se chegue a uma nova visão sobre o objeto aproximam-se das exploratórias. ${ }^{29}$

No ano de 2018 foram consultadas as Constituições de 75 países, ${ }^{30}$ sendo: todos os países que preveem constitucionalmente o esporte, citados pela literatura, da qual destacam-se Bem ${ }^{31}$ e Pachot Zambrana; ${ }^{32}$ todos os países de língua portuguesa e ibero-americanos; todos os países nórdicos, reconhecidos pelo Estado de bem-estar social e implementação do esporte para todos; países de expressão internacional ainda não abarcados pelos demais critérios.

Em cada Constituição foram buscadas informações sobre o esporte e direito ao esporte. A busca foi feita a partir dos descritores "esport", "físic", "recre", "atlet" e "ginast" tendo em vista identificar os dispositivos constitucionais que tratassem do esporte, educação física, cultura física, atividade física, exercício físico, recreação, atletismo, ginástica, entre outros termos derivados dos prefixos adotados. Para Constituições em inglês ou espanhol, procedimento semelhante foi adotado no respectivo idioma.

Além da identificação do texto sobre o esporte em si, foi identificada sua localização dentro da Constituição, no que diz respeito ao Título, Capítulo, Seção ou outro tipo de divisão. A análise quantitativa deu-se em termos de frequência absoluta e relativa, buscando-se identificar características gerais da previsão constitucional do esporte em diferentes blocos de países, em termos de padrões ou singularidades.

A análise qualitativa foi tecida exclusivamente em relação ao direito ao esporte nas Constituições que expressamente o estabelecem, em busca de se traçar um perfil dogmático, tendo como base os elementos constitutivos do direito, bem como sua institucionalidade e a fundamentalidade. O caráter qualitativo emerge neste ponto da pesquisa porque, à pesquisa comparativa quantitativa soma-se o exercício interpretativo e a tentativa de síntese, buscando identificar no texto de cada Constituição ou em padrões textuais de

29 Gil, Antônio Carlos, Métodos e técnicas de pesquisa social, 6. ed., São Paulo, Atlas, 2008, pp. 43 e 44.

30 A versão consultada de cada Constituição foi a vigente no ano de 2018, portanto com as respectivas emendas/atualizações/revisões até tal ano.

31 Schmitt de Bem, Leonardo, op. cit., pp. 57-78.

32 Pachot Zambrana, Karel Luis, El derecho al deporte..., cit., pp. 32-36. 
algumas Constituições, elementos subjacentes do direito ao esporte. Em outras palavras, a partir da construção dogmática tendo como objeto os textos Constitucionais, busca-se compreender o quanto e como as Constituições informam a sociedade e os operadores do direito a respeito do exercício e da garantia do direito ao esporte, respectivamente.

Carvalho ${ }^{33}$ explica que o exercício de análise comparada entre ordenamentos jurídicos pode afigurar-se como objeto ou como método, recebendo a denominação de direito comparado. Quando se trata do caso de um exercício comparado utilizado como método, a ele devem ser acrescidos outros instrumentos de análise, buscando-se chegar à compreensão do objeto. Na presente pesquisa não há a pretensão de adoção do direito comparado propriamente dito, mas sim de utilização de uma análise comparada em busca de conhecer o teor geral do esporte e a dogmática do direito ao esporte em seara constitucional. Daí a busca pela análise de várias Constituições e o exercício comparativo entre as mesmas, somado ao esforço interpretativo no caso específico do direito ao esporte. Dessa forma, sinteticamente, tem-se metodologicamente que o objeto de estudo é o esporte e o direito ao esporte, ao passo que o método é o comparativo somado ao interpretativo-sistemático e as fontes documentais para tal comparação são as 75 Constituições consultadas.

\section{RESULTADOS E DISCUSSÃO}

\section{Características gerais da previsão do esporte nas Constituições}

Os 75 países componentes da amostragem são apresentados no Quadro 01, classificados em ordem alfabética e por continente. ${ }^{34}$

QUADRO 1. CONSTITUIÇÕES ANALISADAS

\begin{tabular}{|l|l|}
\hline $\begin{array}{c}\text { Continente e } \\
\text { Quantidade }\end{array}$ & \multicolumn{1}{|c|}{ Países } \\
\hline África (10) & $\begin{array}{l}\text { África do Sul, Angola, Cabo Verde, Camarões, Egito, Guiné- } \\
\text { Bissau, Guiné Equatorial, Moçambique, Quênia, São Tomé e } \\
\text { Príncipe. }\end{array}$ \\
\hline
\end{tabular}

33 Carvalho, Weliton, "Direito comparado-método ou ciência?", Revista de Informação Legislativa, Brasília, ano 45, núm. 180, outubro-dezembro de 2008, pp. 142 e 143.

34 O texto que abrange o esporte em todas as Constituições citadas no Quadro 1 pode ser encontrado em Canan, Felipe, op. cit., trabalho completo. 


\begin{tabular}{|c|l|}
\hline $\begin{array}{c}\text { Continente } \\
\text { Quantidade }\end{array}$ & \multicolumn{1}{|c|}{ Países } \\
\hline América (25) & $\begin{array}{l}\text { Argentina, Bolívia, Brasil, Canadá, Chile, Colômbia, Costa } \\
\text { Rica, Cuba, El Salvador, Equador, Estados Unidos da América, } \\
\text { Guatemala, Guiana, Haiti, Honduras, Jamaica, México, Nicará- } \\
\text { gua, Panamá, Paraguai, Peru, República Dominicana, Suriname, } \\
\text { Uruguai, Venezuela. }\end{array}$ \\
\hline Ásia (14) & $\begin{array}{l}\text { Afeganistão, Armênia, Camboja, China, Filipinas, Hong Kong, } \\
\text { Japão, Laos, Macau, Síria, Tibet, Timor-Leste, Turquia, Vietnam. }\end{array}$ \\
\hline Europa (25) & $\begin{array}{l}\text { Albânia, Alemanha, Andorra, Bulgária, Croácia, Dinamarca, Es- } \\
\text { lováquia, Espanha, Finlândia, França, Grécia, Hungria, Islândia, } \\
\text { Itália, Lituânia, Macedônia, Noruega, Polônia, Portugal, Repú- } \\
\text { blica Checa, Romênia, Rússia, Suécia, Suíça, Ucrânia. }\end{array}$ \\
\hline Oceania (1) & \begin{tabular}{l} 
Austrália. \\
\hline
\end{tabular}
\end{tabular}

FONTE: elaboração própria.

Países componentes do Reino Unido (Inglaterra, Escócia, País de Gales e Irlanda do Norte), bem como a Nova Zelândia não compuseram a amostra porque não adotam uma Constituição formal, sendo regidos a partir da common $l a w^{35}$ por leis, jurisprudências e tratados internacionais. Austrália e Suécia, embora também não apresentem uma Constituição formal, são regidas por uma série de documentos que têm sido tratados como leis fundamentais.

Das 75 (100\%) Constituições analisadas, 26 (34,67\%) não fazem menção ao esporte ou, no máximo tecem uma previsão genérica que Estado deve possibilitar o desenvolvimento físico das pessoas, em conjunto ao mental, intelectual, cultural, etc. (África do Sul, Alemanha, Andorra, Argentina, Austrália, Canadá, Chile, Costa Rica, Dinamarca, El Salvador, Eslováquia, Estados Unidos da América, Finlândia, França, Guiana, Guiné Equatorial, Haiti, Islândia, Itália, Jamaica, Japão, Noruega, República Checa, Suécia, Timor-Leste e Vietnam). Como é uma previsão genérica considerou-se que não dizem respeito a uma previsão e tampouco regulação mínima do esporte em âmbito constitucional.

O fato da maioria das Constituições analisadas (49 no total ou $65,33 \%$ de 75) prever em alguma medida o esporte em âmbito constitucional cor-

35 Diferente da civil law adotada pela maioria dos países, baseada na formalização de normas jurídicas em documentos escritos, especialmente a Constituição.

Esta obra está bajo una Licencia Creative Commons

Atribución-NoComercial-SinDerivar 4.0 Internacional, IIJ-UNAM. 
robora o entendimento de Pachot Zambrana ${ }^{36}$ de que há uma crescente tendência internacional de valorização e relevância social do esporte.

Dos 49 países que preveem constitucionalmente o esporte de uma maneira específica ou dentro de outra temática (educação ou saúde, por exemplo), 8 (15,33\%) são africanos, $16(32,65 \%)$ americanos, $11(22,45 \%)$ asiáticos, 14 (28,57\%) europeus e nenhum ( $0 \%)$ é da Oceania. Como foram analisados mais países americanos e europeus do que de outros continentes, não é possível afirmar taxativamente que é nestes continentes que encontra-se o maior número de Constituições que regulam o esporte.

Entretanto, considerando que a maioria das Constituições analisadas foi selecionada a partir da literatura, ${ }^{37}$ ou seja, considerando que existe um somatório histórico de esforços em se identificar quais países têm previsão do esporte em sua Constituição, é possível ao menos sugerir que é principalmente em países americanos e europeus que isso acontece. No caso da América identifica-se ainda que somente em países latino-americanos é que ocorre a constitucionalização do esporte.

Deve ficar bastante claro que, assim como explicado nos procedimentos metodológicos, ainda que esteja aqui se adotando genericamente o termo esporte, as Constituições não necessariamente o adotam ou não o fazem com exclusividade, comumente associando-o a correlatos como cultura física ou educação física.

A Tabela 1 apresenta a frequência e percentual de termos ou expressões utilizadas para referir-se às práticas física/corporais em geral nas 49 Constituições que preveem o esporte.

\section{TABELA 1. INCIDÊNCIA DE TERMOS CORRELATOS A ESPORTE NAS CONSTITUIÇÕES}

\begin{tabular}{|l|c|}
\hline \multicolumn{1}{|c|}{ Termo ou expressão utilizado } & Frequência e percentual \\
\hline Somente esporte & $12(24,49 \%)$ \\
\hline Esporte e cultura física & $10(20,41 \%)$ \\
\hline Esporte e educação física & $7(14,29 \%)$ \\
\hline Esporte, educação física e recreação & $4(8,16 \%)$ \\
\hline $\begin{array}{l}\text { Somente outros (treinamento físico, atividades } \\
\text { atléticas, etc.) }\end{array}$ & $4(8,16 \%)$ \\
\hline
\end{tabular}

\footnotetext{
36 Pachot Zambrana, Karel Luis, El derecho al deporte..., cit., pp. 14; 33-36.

37 Ibidem, pp. 32 a 36; Schmitt de Bem, Leonardo, op. cit., pp. 57-78.
} 


\begin{tabular}{|l|c|}
\hline \multicolumn{1}{|c|}{ Termo ou expressão utilizado } & Frequência e percentual \\
\hline Esporte, cultura física e educação física & $2(4,08 \%)$ \\
\hline Esporte, cultura física e recreação & $2(4,08 \%)$ \\
\hline $\begin{array}{l}\text { Esporte, cultura física, educação física e re- } \\
\text { creação }\end{array}$ & $2(4,08 \%)$ \\
\hline Esporte e recreação & $2(4,08 \%)$ \\
\hline Somente cultura física & $2(4,08 \%)$ \\
\hline Somente educação física & $2(4,08 \%)$ \\
\hline Total & $49(100 \%)$ \\
\hline
\end{tabular}

FONTE: elaboração própria.

Se a análise levar em conta somente o termo/expressão isolado percebe-se a seguinte frequência e percentagem nas 49 Constituições que preveem os esporte: $41(83,67 \%)$ vezes esporte, $18(36,73 \%)$ vezes cultura física, 17 (34,69\%) vezes educação física e 10 (20,41\%) vezes recreação. Ainda que a simples interpretação literal dos termos ou expressões não seja suficiente para indicar as especificidades da previsão do esporte em cada Constituição, serve como um primeiro ponto de análise para verificação da compreensão dada ao esporte e sua abrangência.

Como é comumente associado a outros fenômenos relativos ao movimento humano, percebe-se que o esporte tem sido perspectivado sob uma ótica estrita, ou seja, de prática corporal competitiva e regrada institucionalmente. Esta perspectiva é diferente da abrangente, que entende o esporte como sinônimo de práticas física/corporais em geral, comumente adotada nos países em que há difusão do esporte para todos. ${ }^{38}$

Em relação à cultura física, Cazorla Prieto ${ }^{39}$ explica que a expressão teria sido criada na URSS e depois difundida dentre os países comunistas/ socialistas no início do século XX, relacionada à educação e desenvolvimento físico das pessoas e como alternativa ao esporte de competição que, naquelas localidades representava o ideal burguês surgido no capitalismo. A expressão cultura física acabaria sendo o equivalente comunista/socia-

38 Ministros Europeos Responsables del Deporte, Carta Europea del Deporte para Todos, Universidad de Córdoba, 1975, disponível em: https://www.uco.es/deportes/media/documentacion/Carta\%20Europea\%20del\%20Deporte\%20para\%20todos.pdf, acesso em 13 set. 2018, p. 2; Bergsgard, Nils Asle et al., Sport Policy: a comparative analysis of stability and change, Oxford, Elsevier, 2007, pp. 201-203.

39 Cazorla Prieto, Luis María, op. cit., p. 175.

Esta obra está bajo una Licencia Creative Commons

Atribución-NoComercial-SinDerivar 4.0 Internacional, IIJ-UNAM. 
lista do esporte para todos liberal/capitalista, ambos voltados à superação do esporte como prática exclusivamente voltada à competição institucionalizada. Como resultado, posteriormente, países comunistas/socialistas acabaram adotando também o termo esporte e países liberais/capitalistas acabaram adotando também a expressão cultura física.

A única Constituição que conceitua em alguma medida a cultura física é a do Equador, estabelecendo em seu Art. 381 que ela “...compreende o esporte, a Educação Física e a recreação, como atividades que contribuem para a saúde, formação e desenvolvimento integral de pessoas". Como aponta Flores Fernández, ${ }^{40}$ a Lei Geral de Cultura Física e Esporte de 2013 do México define, no inciso II do Art. 5, cultura física como "Conjunto de bens, conhecimentos, ideias, valores e elementos materiais que o homem tem produzido em relação ao movimento e uso do seu corpo". No inciso I do Art. 5 estabelece a Educação Física como "O meio fundamental para adquirir, transmitir e acrescentar a cultura física".

Pela lógica dos conceitos de esporte e cultura física, pelo teor dos textos constitucionais em geral, exemplificados pelo excerto da Constituição do Equador e mais detalhadamente no desdobramento feito pela Lei mexicana, entende-se que educação física refere-se à disciplina escolar. Nos textos constitucionais, comumente é associada diretamente à escola e/ou educação e conjugada ao termo esporte e/ou expressão cultura física, o que indica serem entendidos como instâncias/contextos de práticas físicas/ corporais diferentes. Além disso, em muitos países, a Educação Física não compõe uma área de conhecimento e/ou uma profissão legalmente reconhecida para além do contexto escolar.

Esse esforço de delineamento conceitual mostra-se importante para que cada fenômeno abrangido pela Constituição não seja mal interpretado. Ao mesmo tempo serve para que o exercício comparado não trate fenômenos distintos como semelhantes ou fenômenos semelhantes como distintos. Comparar a previsão do esporte a partir de uma Constituição que teleologicamente o perspectiva em sentido estrito com outra que o concebe em sentido lato pode mostrar-se um equívoco, pois a função social esperada do esporte em cada qual possivelmente é diferente. A associação ou não do esporte a outros termos/expressões pode contribuir para se identificar

40 Flores Fernández, Zitlally, "El derecho al deporte en México”, cit., p. 57. 
a abrangência daquilo que se pretende constitucionalmente das práticas físicas/corporais à sociedade.

Pela lógica da maioria dos textos constitucionais analisados, assim, o esporte é perspectivado sob uma ótica estrita de práticas físicas corporais competitivas e institucionalizadas, mas em contrapartida existe uma preocupação abrangente com práticas físicas/corporais em geral, pois é associado outro termo ou expressão na maioria das Constituições. Dito de outro modo, a regulação constitucional do esporte não se restringe ao esporte de competição, abrangendo também as práticas físicas/corporais em geral, comumente abarcadas pela expressão cultura física e tendo como principal lócus de manifestação a educação física escolar.

Em relação às áreas de atuação estatal agregadas ao esporte identifica-se que, dentre as 49 Constituições, 17 (34,69\%) relacionam-no à saúde; $17(34,69 \%)$ à educação; $6(12,24 \%)$ à cultura; $6(12,24 \%)$ ao lazer; $5(10,2 \%)$ ao código nacionalista, ou seja, ao uso do esporte como símbolo para promoção do nacionalismo; e 31 (63,27\%) prevêem em algum de seus dispositivos o esporte dissociado de qualquer outra área de atuação estatal, o que representa uma maior institucionalidade e sugere uma maior legitimação social. O percentual total supera os 100\% porque muitas Constituições relacionam o esporte a mais de uma área de atuação estatal. A partir desses dados verifica-se que o esporte é tanto perspectivado como meio para outros fins em busca do desenvolvimento humano integra, qualidade de vida e/ou dignidade humana, quanto como fim em si mesmo, neste caso justificado por se tratar de um patrimônio cultural historicamente construído.

Corrobora o fato de que 24 (48,98\%) Constituições destinam, no mínimo, um dispositivo (título, capítulo e/ou artigo) exclusivo para prever o esporte (e não apenas um inciso ou alínea dentro de um dispositivo mais geral, relativo a algumas ou várias áreas), e 32 (65,31\%) estabelecem um dever específico do Estado/poder público para desenvolvê-lo.

Dentre os 49 países que apresentam a previsão constitucional do esporte, $14(28,67 \%)$ estabelecem expressamente o direito ao esporte (Angola, Bolívia, Brasil, Cabo Verde, Colômbia, Cuba, Egito, Equador, México, Moçambique, Nicarágua, Portugal, República Dominicana e Venezuela). Esse montante equivale também a $18,67 \%$ do total de 75 Constituições analisadas. 
Pachot Zambrana ${ }^{41}$ identificou o direito ao esporte nas Constituições de Cuba, Portugal, Nicarágua, Brasil, Colômbia e Venezuela. Bem ${ }^{42}$ identificou nas Constituições de Bolívia, Brasil, Cabo Verde, Cuba, Moçambique, Nicarágua, Portugal, República Dominicana e Venezuela. E Flores Fernández, ${ }^{43}$ referindo-se exclusivamente a Constituições de países latino-americanos, lista que o direito ao esporte encontra-se previsto no Brasil, Cuba, Colômbia, Guatemala, Nicarágua, Paraguai, Venezuela e México. A autora interpreta que Guatemala e Paraguai também estabelecem o direito ao esporte, ainda que expressamente prevejam somente o dever do Estado/ poder público.

Sobre essa questão verifica-se que as 14 Constituições que preveem expressamente o direito ao esporte encontram-se no grupo das 32 que estabelecem o dever do Estado/poder público (43,75\% de 32), o que significa que 18 (36,73\% de 49 e 56,25\% de 32) Constituições atribuem um dever de desenvolvimento do esporte para o Estado/poder público, mas não estabelecem expressamente um direito às pessoas. As demais 17 (34,69\% de 49) que preveem e/ou regulam em alguma medida o esporte não estabelecem nem dever ao Estado/poder público e nem direito às pessoas.

A dicotomia entre os textos que preveem o esporte como um dever do Estado/poder público e os textos que expressamente estabelecem o esporte como direito é uma temática importante que permeia as discussões sobre o esporte no âmbito da análise comparada de Constituições. Cazorla Prieto ${ }^{44}$ e Castilla ${ }^{45}$ compreendem que a previsão do dever sem concomitância do direito não permite que se interprete pela existência de um direito implícito. De outro lado, Bem ${ }^{46}$ compreende que a simples previsão constitucional de um dever do Estado é suficiente para se presumir o direito, mesmo que este não seja expressamente estabelecido. Pachot Zambrana ${ }^{47}$ contribui para discussão do tema, mas não toma expressamente partido para algum dos lados.

\footnotetext{
41 Pachot Zambrana, Karel Luis, El derecho al deporte..., cit., pp. 14; 37 e 38.

42 Schmitt de Bem, Leonardo, op. cit., pp. 70-78.

43 Flores Fernández, Zitlally, "La cultura física...", cit., p. 187.

44 Cazorla Prieto, Luis María, op. cit., pp. 193-198.

45 Castilla, Karlos, op. cit., pp. 103 e 104.

46 Schmitt de Bem, Leonardo, op. cit., p. 59.

47 Pachot Zambrana, Karel Luis, El derecho al deporte..., cit., pp. 35 e 36; Pachot Zambrana, Karel Luis, "El derecho constitucionl...”, cit., pp. 124-126.
} 
Na primeira tendência, como defende Cazorla Prieto, ${ }^{48}$ o cidadão não é contemplado diretamente como um titular do direito, mas tão somente como um usuário dos serviços públicos, ou, em outros termos, um objeto da atividade do Estado. Assim, num exemplo hipotético, se a pessoa sentir-se prejudicada por não estar tendo acesso à prática esportiva, pode demandar juridicamente o Estado, mas este pode alegar que está cumprindo seu dever, pois que realiza diversas ações frente ao esporte (educação física escolar, financiamento da iniciativa privada, entre outros possíveis exemplos), mesmo que elas não atinjam diretamente o demandante. Como a ele não é expressamente garantido o direito constitucional, teria que aceitar que o Estado, no exemplo apresentado, estaria cumprindo com seu dever.

$\mathrm{Na}$ outra tendência, $\mathrm{Bem}^{49}$ argumenta que, se a Constituição estabelece um dever ao Estado é porque existe um direito correspondente das pessoas. Fosse este o caso, no exemplo hipotético utilizado acima, a pessoa que demandasse o Estado teria direito a ganho de causa, com consequente acesso à prática esportiva garantido. Como argumento contrário à esta tendência encontra-se o fato de que não haveria necessidade de prever direitos expressamente ou, inversamente, caso o direito fosse previsto não haveria a necessidade de prever deveres ao Estado/poder público.

Adota-se neste artigo a compreensão de que a discussão, no fundo, perpassa a questão da fundamentalidade. Além de cumprir com os quesitos da fundamentalidade formal, tem-se a impressão de que uma previsão expressa do direito garante ao esporte também uma maior fundamentalidade material do que ocorre com a simples previsão do dever do Estado/poder público. Uma potencialidade de exigência da pessoa frente ao Estado seria indubitavelmente maior no caso de haver um direito expresso e aumentaria se, em conjunto ao direito dos titulares fosse estabelecido o dever do Estado e/ou de outros destinatários.

Sobre a questão da fundamentalidade, inclusive, verifica-se que, de todos os 49 países que preveem constitucionalmente o esporte, 33 (67,35\%) o fazem dentro do título ou capítulo destinado à previsão e/ou estabelecimento de direitos. Das 32 que preveem o dever do Estado/poder público para com o esporte, 22 (44,9\% de 49 ou $68,75 \%$ de 32$)$ o enquadram no título/capítulo específico para estabelecer direitos. Se considerados somente os 14 países que estabelecem expressamente o direito ao esporte,

\footnotetext{
48 Cazorla Prieto, Luis María, op. cit., pp. 193-198.

49 Schmitt de Bem, Leonardo, op. cit., p. 59. 
$13(26,53 \%$ de $49,40,63 \%$ de 32 ou $92,86 \%$ de 14$)$ tratam deste direito no título ou capítulo relativo à previsão e/ou estabelecimento de direitos, sendo a única exceção o Brasil.

Deve-se ponderar que a forma como cada país organiza sua Constituição e como interpreta os direitos fundamentais varia. Em algumas Constituições, por exemplo, direitos sociais ou culturais são previstos como parte dos direitos fundamentais, ao passo que em outras são previstos à parte. Concorda-se com Bem,,$^{50}$ quando afirma que o fato de Constituições albergarem o esporte no título/capítulo dedicado ao estabelecimento de direitos não significa obrigatoriamente que o tratem como um direito, se não for assim expressamente estabelecido.

Em relação à fundamentalidade material, ainda que os textos das Constituições que preveem expressamente o direito ao esporte comumente sejam mais completos e complexos, com maior institucionalidade, existem exceções. As Constituições de Egito e México, por exemplo, preveem sucintamente o direito e pouco oferecem diretrizes sobre como garanti-lo. A Constituição do Brasil, embora relativamente abrangente em relação ao esporte mostra-se confusa em relação à natureza do direito e especialmente às formas de garanti-lo.

A Constituição da Guatemala, a contrário, não prevê o direito, mas, em compensação é a única que estabelece um percentual mínimo de destinação de fundos públicos para o esporte, na ordem de $3 \%$. O montante deve ser destinado para os organismos esportivos privados, educação física escolar, esporte escolar, recreação e esporte não federado, seguindo percentuais estabelecidos pela própria Constituição. Os organismos esportivos privados gozam ainda de isenção fiscal.

A Constituição de Filipinas, embora também na preveja o direito e não se mostre tão concreta quanto a da Guatemala, apresenta um texto coerente, que informa as bases do desenvolvimento esportivo nacional, mencionando o Estado deve contribuir para promoção de variados contextos esportivos, como a educação física escolar, ligas esportivas, esportes amadores e treinamento para competições internacionais. Determina ainda que instituições educacionais devem estabelecer parcerias com clubes e entidades diversas para garantir a promoção de práticas esportivas regulares.

$50 \quad$ Ibidem, p. 66. 
Ao passo que a maioria das Constituições trata o esporte sob uma perspectiva de democratização, ou seja, de criação/ampliação do acesso das pessoas em geral à prática esportiva, $6(12,24 \%)$ expressamente abrem precedentes para intervenção/fomento estatal ao esporte de elite, que pode gerar representação nacional, mas é destinado à expressiva minoria da população (Brasil, Equador, Guatemala, Paraguai, República Dominicana e Venezuela). Inclusive, somente Equador e Paraguai especificam que o financiamento do esporte de elite destina-se à representação nacional em competições internacionais. Filipinas e Egito não mencionam o esporte de elite, mas determinam respectivamente a promoção do treinamento para competições internacionais e o dever estatal de descobrir e patrocinar atletas talentosos.

Em relação exclusivamente aos 14 países que estabelecem expressamente o direito ao esporte em suas Constituições, a partir de uma análise da configuração geoespacial tem-se que, no tocante à divisão continental, 4 são africanos (28,57\%), 9 americanos $(64,29 \%)$ e 1 europeu $(7,14 \%)$. Em relação ao idioma, 5 (35,71\%) são de língua portuguesa (Angola, Brasil, Cabo Verde, Moçambique e Portugal), 8 (57,14\%) são de língua espanhola (Bolívia, Colômbia, Cuba, Equador, México, Nicarágua, República Dominicana e Venezuela) e 1 (7,14\%) é de outro idioma (Egito). Identifica-se que o direito constitucional ao esporte é mais prevalente em países americanos e de língua espanhola.

Se levados em conta os blocos culturais de países, tem-se que dentre os 22 países da Organização de Estados Ibero-americanos (Argentina, Bolívia, Brasil, Chile, Colômbia, Costa Rica, Cuba, El Salvador, Equador, Espanha, Guatemala, Guiné Equatorial, Honduras, México, Nicarágua, Panamá, Paraguai, Peru, Portugal, República Dominicana, Uruguai e Venezuela), o direito ao esporte é previsto em 10, o que corresponde a $45,45 \%$ dos 22 ou $71,43 \%$ dos 14 . Dentre os 20 países latino-americanos (Argentina, Bolívia, Brasil, Chile, Colômbia, Costa Rica, Cuba, El Salvador, Equador, Guatemala, Haiti, Honduras, México, Nicarágua, Paraná, Paraguai, Peru, República Dominicana, Uruguai, Venezuela), o direito ao esporte é previsto em 9, o que corresponde a $45 \%$ dos 20 ou $64,29 \%$ dos 14. E dentre os 9 países da Comunidade dos Países de Língua Portuguesa (Angola, Brasil, Cabo Verde, Guiné-Bissau, Guiné Equatorial, Moçambique, Portugal, São Tomé e Príncipe e Timor-Leste) 
o direito ao esporte é previsto em 5, o que corresponde a 55,56\% dos 9 ou $35,71 \%$ dos 14 .

Pachot Zambrana ${ }^{51}$ e Castilla ${ }^{52}$ apontam que o direito ao esporte encontra-se majoritariamente previsto em Constituições de países latino-americanos. Entretanto, pelos dados elencados identifica-se que, em termos absolutos o maior contingente encontra-se em países ibero-americanos e não somente latino-americanos e, em termos relativos/percentuais sobressaem-se os países de língua portuguesa. Ou seja, dentro dos blocos culturais de países, o que tem maior percentual de Constituições que estabelecem o direito ao esporte em relação ao total de países do bloco é o de língua portuguesa.

Essa prevalência do direito constitucional ao esporte em países de origem/colonização/cultura espanhola e portuguesa pode ser explicada por vários fatores, tais como similaridades sócio-jurídico-político-econômicas, idioma, influência dos textos de Cuba (1976a) e Portugal (1976a) que inauguraram previsões amplas do esporte e do direito ao esporte, e até mesmo a repercussão e difusão da obra de Cazorla Prieto, ${ }^{53}$ multicitada e reproduzida na literatura em espanhol e português da área. O caráter de common law em países de origem anglo-saxã também pode ser um fator explicativo para maior prevalência do direito constitucional ao esporte em países ibero-americanos e/ou de língua portuguesa. Importante destacar que naqueles países, ainda que seja pouco comum a adoção de uma Constituição escrita/formal e que, portanto, não haja previsão formal do direito ao esporte, existe grande difusão do esporte para todos, ou seja, de uma plataforma política de universalização, popularização e/ou democratização das práticas físicas/corporais. ${ }^{54}$

\section{A DOGMÁTICA DO DIREITO AO ESPORTE EM ÂMBITO CONSTITUCIONAL}

A partir da identificação de questões gerais sobre o esporte e especialmente sobre o direito ao esporte em sede constitucional, é possível se esta-

\footnotetext{
51 Pachot Zambrana, Karel Luis, El derecho al deporte..., cit., pp. 35, 82 e 102.

52 Castilla, Karlos, op. cit., pp. 102, 104, 123 e 125.

53 Cazorla Prieto, Luis María, op. cit., trabalho completo.

54 Bergsgard, Nils Asle et al., op. cit, pp. 201-242.
} 
belecer o exercício jurídico-interpretativo de construção dogmática. Para que o exercício dogmático realizado possa ficar mais visível e concreto apresenta-se no quadro 2 o texto sobre o direito ao esporte em todas as Constituições que expressamente o estabelecem.

\section{QUADRO 2. TEXTOS SOBRE O DIREITO AO ESPORTE NAS CONSTITUIÇÕES QUE O ESTABELECEM}

\begin{tabular}{|c|c|}
\hline País & Texto constitucional sobre o direito ao esporte \\
\hline Angola & $\begin{array}{l}\text { Título II - Direitos e Deveres Fundamentais. Capítulo II - Direitos, } \\
\text { Liberdades e Garantias Fundamentais. Seç̧ão II - Garantia dos Di- } \\
\text { reitos e Liberdades Fundamentais. Capítulo III - Direitos e Deveres } \\
\text { Econômicos, Sociais e Culturais. } \\
\text { Artigo } 79 \text { (Direito ao ensino, cultura e desporto) - 1. O Estado pro- } \\
\text { move o acesso de todos à alfabetização, ao ensino, à cultura e ao } \\
\text { desporto, estimulando a participação dos diversos agentes particu- } \\
\text { lares na sua efetivação, nos termos da lei. 3. A iniciativa particular e } \\
\text { cooperativa nos domínios do ensino, da cultura e do desporto exer- } \\
\text { ce-se nas condições previstas na lei. } \\
\text { Artigo } 81 \text { (Juventude) - 1. Os jovens gozam de proteção especial } \\
\text { para efetivação dos seus direitos econômicos, sociais e culturais, } \\
\text { nomeadamente: d) na educação física e no desporto. }\end{array}$ \\
\hline Bolívia & $\begin{array}{l}\text { Primeira Parte - Bases Fundamentais do Estado - Direitos, Deveres } \\
\text { e Garantias. Título III - Direitos Fundamentais e Garantias. Capítu- } \\
\text { lo Sexto - Educação, Interculturalidade e Direitos Culturais. Seção } \\
\text { V - Esporte e Recreação. } \\
\text { Artigo } 104 \text { - Toda pessoa tem direito ao esporte, à cultura física e } \\
\text { à recreação. O Estado garante o acesso ao esporte sem distinção de } \\
\text { gênero, idioma, religião, orientação política, localização territorial, } \\
\text { classe (pertencimento) social, cultural ou qualquer outro tipo. } \\
\text { Artigo } 105 \text { - O Estado promoverá, por meio de políticas de edu- } \\
\text { cação, recreação e saúde pública, o desenvolvimento da cultura } \\
\text { física e da prática esportiva em seus níveis preventivo, recreati- } \\
\text { vo, formativo e competitivo, com especial atenção às pessoas com } \\
\text { deficiência. O Estado garantirá os meios e os recursos econômicos } \\
\text { necessários para sua efetividade. }\end{array}$ \\
\hline
\end{tabular}


Brasil Título VIII - Da Ordem Social. Capítulo III - Da Educação, da Cultura e do Desporto. Seção III - Do Desporto.

Art. 217. É dever do Estado fomentar práticas desportivas formais e não-formais, como direito de cada um, observados:

I - a autonomia das entidades desportivas dirigentes e associações, quanto a sua organização e funcionamento;

II - a destinação de recursos públicos para a promoção prioritária do desporto educacional e, em casos específicos, para a do desporto de alto rendimento;

III - o tratamento diferenciado para o desporto profissional e o nãoprofissional;

IV - a proteção e o incentivo às manifestações desportivas de criação nacional.

$\S 3^{\circ} \mathrm{O}$ Poder Público incentivará o lazer, como forma de promoção social.

Cabo Verde Parte II - Direitos e Deveres Fundamentais. Título III - Direitos e Deveres Econômicos, Sociais e Culturais.

Artigo $80^{\circ}$ (Direito à cultura física e ao desporto) - 1. A todos é reconhecido o direito à cultura física e ao desporto. 2. Para garantir o direito à cultura física e ao desporto, aos poderes públicos em colaboração com as associações, coletividades desportivas, escolas e demais agentes desportivos incumbe designadamente: a) Estimular a formação de associações e coletividades desportivas; b) Promover a infra-estruturação desportiva do país; c) Estimular, orientar e apoiar a prática e a difusão da cultura física e do desporto; d) Prevenir a violência no desporto.

Colômba Título II - Dos Direitos, Garantias e Deveres. Capítulo 2 - Dos Direitos Sociais, Econômicos e Culturais.

Artigo 52 - O exercício do esporte, suas manifestações recreativas, competitivas e autóctones têm como função a formação integral das pessoas, preservar e desenvolver uma melhor saúde no ser humano. O esporte e a recreação fazem parte da educação e constituem um gasto público social. Se reconhece o direito de todas as pessoas à recreação, à prática esportiva e ao aproveitamento do tempo livre. O Estado fomentará essas atividades e inspecionará, monitorará e controlará as organizações esportivas e recreativas cuja estrutura e propriedade deverão ser democráticas. 


\begin{tabular}{|l|l|}
\hline Cuba & Capítulo I. Fundamentos Políticos, Sociais e Econômicos do Es- \\
tado. & Artigo 9 - O Estado: b) como poder do povo, ao serviço do próprio \\
povo, garante: 6. Que não haja pessoa que não tenha acesso ao es- \\
tudo, à cultura e ao esporte; \\
Capítulo V - Educação e Cultura. \\
Artigo 39 - Em sua política educacional e cultural [o Estado] ade- \\
re aos seguintes postulados: c. promover a educação patriótica e a \\
formação comunista das novas gerações e a preparação de crian- \\
ças, jovens e adultos para a vida social. Para realizar este princípio, \\
combina-se a educação geral... com... educação física, esporte... O \\
Estado guia, fomenta e promove a cultura física e o esporte em \\
todas as suas manifestações como meio de educação e contribuição \\
para a formação integral dos cidadãos; \\
Capítulo VII - Direitos, Deveres e Garantias Fundamentais. \\
Artigo 52 - Todos têm direito à educação física, ao esporte e à re- \\
creação. O gozo deste direito é garantido pela inclusão do ensino \\
e da prática da educação física e do esporte nos planos de estudo \\
do sistema nacional de educação; e pela amplitude da instrução e \\
dos meios colocados à disposição do povo, que facilitem a prática \\
massiva do esporte e da recreação. \\
Capítulo Três - Direitos públicos, Liberdades e Deveres. \\
Artigo 84 (Esporte) - O estado garante o direito de todos de pratica- \\
rem esportes físicos. As instituições do Estado e a sociedade devem \\
trabalhar para descobrir e patrocinar atletas talentosos e tomar as \\
medidas necessárias para incentivar a prática do esporte.
\end{tabular}




\begin{tabular}{|c|c|}
\hline Equador & $\begin{array}{l}\text { Título II - Direitos. Capítulo Dois - Direitos de Bem Viver. Quarta } \\
\text { Seção - Cultura e Ciência. } \\
\text { Art. } 24 \text { - As pessoas têm direito à recreação e lazer, à prática espor- } \\
\text { tiva e ao tempo livre. } \\
\text { Sétima Seção - Saúde. } \\
\text { Art. } 32 \text { - A saúde é um direito garantido pelo Estado, cuja realiza- } \\
\text { ção está ligada ao exercício de outros direitos, incluindo o direito } \\
\text { à... cultura física... } \\
\text { Capítulo Sexto - Direitos de Liberdade. } \\
\text { Art. } 66 \text { - Se reconhece a garante às pessoas: } 2 \text {. O direito a uma vida } \\
\text { digna, que assegura... cultura física... } \\
\text { Título VII - Regime de Bem Viver. Capítulo Primeiro - Inclusão e } \\
\text { Equidade. Seção Seis - Cultura Física e Tempo Livre. } \\
\text { Art. } 381 \text { - O Estado protegerá, promoverá e coordenará a cultura } \\
\text { física, que compreende o esporte, a educação física e a recreação, } \\
\text { como atividades que contribuem para a saúde, formação e desen- } \\
\text { volvimento integral de pessoas; impulsionará o acesso em massa ao } \\
\text { esporte e a atividades esportivas ao nível formativo, de vizinhan- } \\
\text { ça e paroquial; patrocinará a preparação e participação de atletas } \\
\text { em competições nacionais e internacionais, que incluem os Jogos } \\
\text { Olímpicos e Paralímpicos; e fomentará a participação de pessoas } \\
\text { com deficiência. O Estado garantirá os recursos e a infra-estrutu- } \\
\text { ra necessários para estas atividades. Os recursos se sujeitarão ao } \\
\text { controle estatal e prestação de contas e deverão ser distribuídos de } \\
\text { forma eauitativa }\end{array}$ \\
\hline México & $\begin{array}{l}\text { Título Primeiro. Capítulo I - Dos Direitos Humanos e suas Garan- } \\
\text { tias. } \\
\text { Artigo } 4 \text { - Toda pessoa tem direito à cultura física e à prática do } \\
\text { esporte. O Estado é responsável pela sua promoção, fomento e es- } \\
\text { tímulo de acordo com as leis sobre o assunto. }\end{array}$ \\
\hline $\begin{array}{l}\text { Moçambi- } \\
\text { que }\end{array}$ & $\begin{array}{l}\text { Título III - Direitos, Deveres e Liberdades Fundamentais. Capítulo } \\
\text { V - Direitos e Deveres Econômicos, Sociais e Culturais. } \\
\text { Artigo } 93 \text { (Cultura física e desporto) - 1. Os cidadãos têm direito } \\
\text { à educação física e ao desporto. 2. O Estado promove, através das } \\
\text { instituições desportivas e escolares, a prática e a difusão da educa- } \\
\text { ção física e do desporto. }\end{array}$ \\
\hline
\end{tabular}




\begin{tabular}{|c|c|}
\hline Nicarágua & $\begin{array}{l}\text { Título IV - Direitos, Deveres e Garantias do Povo. Capítulo III. } \\
\text { Direitos Sociais. } \\
\text { Artigo } 65 \text { - Os nicaraguenses têm direito ao esporte, à educação } \\
\text { física, à recreação e ao lazer. O Estado impulsionará a prática do } \\
\text { esporte e da educação física, por meio da participação organizada e } \\
\text { massiva do povo, para a formação integral dos nicaraguenses. Isso } \\
\text { será feito com programas e projetos especiais. }\end{array}$ \\
\hline Portugal & $\begin{array}{l}\text { Capítulo II - Direitos e Deveres Sociais. } \\
\text { Artigo } 64 .^{\circ} \text { (saúde) - } 2 . \text { O direito à proteção da saúde é realizado: B) } \\
\text {...pela promoção da cultura física e desportiva... } \\
\text { Artigo } 70 .^{\circ} \text { (juventude) - } 1 \text {. Os jovens gozam de proteção especial } \\
\text { para efetivação dos seus direitos econômicos, sociais e culturais, } \\
\text { nomeadamente: D) na educação física e no desporto; } \\
\text { Capítulo III - Direitos e Deveres Culturais. } \\
\text { Artigo } 79 .^{\circ} \text { (cultura física e desporto) - } 1 \text {. Todos têm direito à cultu- } \\
\text { ra física e ao desporto. } 2 \text {. Incumbe ao Estado, em colaboração com } \\
\text { as escolas e as associações e coletividades desportivas, promover, } \\
\text { estimular, orientar e apoiar a prática e a difusão da cultura física e } \\
\text { do desporto, bem como prevenir a violência no desporto. }\end{array}$ \\
\hline $\begin{array}{l}\text { Repúblia } \\
\text { Dominicana }\end{array}$ & $\begin{array}{l}\text { Título II - Dos Direitos, Garantias e Deveres Fundamentais. Capí- } \\
\text { tulo I - De Direitos Fundamentais. Seção III - Dos Direitos Cultu- } \\
\text { rais e Esportivos. } \\
\text { Artigo } 65 \text { - Direito ao esporte. Toda pessoa tem direito à educação } \\
\text { física, ao esporte e à recreação. Cabe ao Estado, em colaboração } \\
\text { com centros de ensino e organizações esportivas, fomentar, incen- } \\
\text { tivar e apoiar a prática e difusão dessas atividades. Para tanto: 1) } \\
\text { O Estado assume o esporte e a recreação como política pública de } \\
\text { educação e saúde e garante a educação física e o esporte escolar } \\
\text { em todos os níveis do sistema educacional, de acordo com a lei; } 2) \\
\text { A lei fornecerá recursos, estímulos e incentivos para a promoção } \\
\text { do esporte para todos e todas, a atenção integral aos esportistas, o } \\
\text { apoio ao esporte de alta competição, aos programas e atividades } \\
\text { esportivas no país e no exterior. }\end{array}$ \\
\hline
\end{tabular}


Venezuela Título III - Dos Deveres, Direitos Humanos e Garantias. Capítulo VI - Dos Direitos Culturais e Educacionais.

Artigo 111 - Todas as pessoas têm direito ao esporte e à recreação como atividades que beneficiam a qualidade da vida individual e coletiva. O Estado assumirá o esporte e a recreação como política de educação e saúde pública e garantirá os recursos para sua promoção. A educação física e o esporte desempenham um papel fundamental na formação integral de crianças e adolescentes. Seu ensino é obrigatório em todos os níveis da educação pública e privada até o ciclo diversificado, com as exceções que estabeleça a lei. O Estado garantirá atenção integral aos e as esportistas sem discriminação, bem como apoio ao esporte de alta competição e à avaliação e regulamentação de entidades esportivas do setor público e privado, de acordo com a lei. A lei estabelecerá incentivos e estímulos às pessoas, instituições e comunidades que promovam os e as atletas e desenvolvam ou financiam planos, programas e atividades esportivas no país.

FONTE: Constituições consultadas. Elaboração: os autores.

O exercício dogmático não desconsidera que existem diferenças entre as Constituições e os países, mas busca identificar padrões relativos a cada elemento constitutivo do direito ao esporte, o que não significa deixar de apontar singularidades. Ao mesmo tempo, o padrão não significa que $100 \%$ das Constituições se encaixam, mas ao menos a maioria delas ao menos se aproxima dele.

Em relação ao destinatário percebe-se uma maior incidência do poder público do que exclusivamente do Estado. Parece existir uma tendência de o Estado deixar de assumir com exclusividade a responsabilidade pelo desenvolvimento do direito ao esporte, passando a dividi-la com instituições esportivas privadas e escolares, como pode ser identificado em 7 (50\%) Constituições (Cabo Verde, Colômbia, Egito, Moçambique, Portugal, República Dominicana e Venezuela). Nesses casos, é interessante que haja no ordenamento jurídica do cada país uma lei que defina mais especificamente as responsabilidades de cada destinatário, evitando que uns desresponsabilizem-se perante os outros.

No caso brasileiro, atribui-se dever exclusivamente ao Estado, que, além disso, garante autonomia às instituições esportivas privadas, mas não 
as responsabiliza frente ao desenvolvimento do esporte e tampouco do direito ao esporte.

No que diz respeito aos titulares identifica-se que há um padrão de abrangência de todas as pessoas, embora haja especial atenção ao público infanto-juvenil, atendido predominantemente pela educação física escolar. Nas Constituições que preveem o esporte de elite, a titularidade acaba abrangendo também os atletas que dele fazem parte. Neste caso, contudo, como sugere Castilla, ${ }^{55}$ a característica do direito é diferenciada, relacionando-se mais a direitos trabalhistas do que ao direito à prática esportiva propriamente dita.

O objeto do direito ao esporte no seio da análise comparada, como adverte Pachot Zambrana, ${ }^{56}$ não é e nem pode ser simplesmente o esporte, sem que haja uma especificação mínima sobre seu conceito ou sua abrangência. $\mathrm{O}$ autor menciona a primeira diferenciação entre direito à prática esportiva e direito de acesso à prática esportiva. No primeiro caso, o direito é essencialmente de primeira dimensão, de liberdade, ao passo que no segundo caso o direito é de segunda dimensão, de caráter social, exigindo prestações por parte do Estado e/ou outros destinatários.

Num esforço de interpretação das Constituições aloca-se em ambas as possibilidades, abrangendo, no caso do direito à prática esportiva, a garantia de liberdade de prática e, no caso do direito de acesso à prática esportiva, essencialmente a oferta de educação física escolar e do esporte para todos ou cultura física, isto é, da prática física/corporal/esportiva não necessariamente competitiva por todas as pessoas. Além da previsão especial de garantia ao público infanto-juvenil e à comum citação de escolas como lócus de exercício e garantia do direito ao esporte, sua associação às expressões cultura física e educação física contribui para este entendimento. De uma forma geral, assim, o objeto do direito ao esporte em seara constitucional comparada basicamente abrange a possibilidade de acesso de todas as pessoas às práticas físicas/corporais em geral.

Especificamente em relação ao esporte de elite verifica-se que é pouco prevalente nas Constituições e, por ser destinado a poucas pessoas não é abrangido pelo direito. Ainda que componha um dever do Estado nas Constituições que o preveem e que em alguma medida encontre-se inserido na ideia de esporte para todos/cultura física, o fato de ser pouco

\footnotetext{
55 Castilla, Karlos, op. cit., p. 114.

56 Pachot Zambrana, Karel Luis, El derecho al deporte..., cit., p. 43. 
previsto não permite que seja enquadrado como objeto do direito ao esporte tendo-se em conta a perspectiva comparada. Ou seja, representa uma singularidade e não um padrão.

Tendo em vista a abrangência quase sem limitação do objeto e levando-se em conta as limitações de caráter socioeconômico de muitos países, especialmente no sentido de reserva do possível que por si só impediria a garantia inconteste do direito ao esporte, a identificação do núcleo essencial torna-se indispensável.

Percebe-se, assim, que o núcleo essencial encontra-se na liberdade/autonomia de prática e associação, obrigatoriedade da educação física escolar e na geração de facilidades ao acesso de todos à prática esportiva e cultura física. Essas facilidades de acesso não significam necessariamente a oferta de serviços (ainda que possam abrangê-los), estando mais relacionadas à disposição de equipamentos às pessoas. Isso pode ser observado nas Constituições de Cuba, República Dominicana e Venezuela, que estabelecem a obrigatoriedade da educação física escolar em todo o ciclo escolar; do Brasil que prioriza o esporte educacional; e de Cabo Verde, Cuba, Equador e República Dominicana, que prevêem expressa e objetivamente o dever do Estado frente à infraestrutura e desenvolvimento do esporte para todos/ cultura física. As demais Constituições ainda que não tão expressa ou expressivamente, dão indícios a respeito, transformando em padrão aquilo que encontra-se claro nas citadas. Pachot Zambrana, ${ }^{57}$ a exemplo do que foi anteriormente apresentado, embora não especifique objetivamente o núcleo essencial, também identifica que perpassa uma dimensão abstencionista e outra prestacional por parte do Estado/poder público.

Os limites do direito são estritamente relacionados ao ordenamento constitucional e jurídico como um todo de cada país, de forma que é difícil apontá-los num exercício de direito comparado. Entretanto, tendo em vista o padrão identificado como núcleo essencial, pode-se inferir que os limites do direito ao esporte a partir da perspectiva comparada abrangem quaisquer ações que não contrariem a liberdade de prática e associação, a obrigatoriedade da educação física escolar e a criação de condições mínimas de infraestrutura para prática do esporte para todos/cultura física.

A institucionalidade, a exemplo dos limites, depende muito de cada ordenamento jurídico específico, especialmente de caráter infraconstitucional. Embora também não seja plenamente possível de ser identificada em

\footnotetext{
$57 \quad$ Ibidem, p. 43 .
} 
uma análise de caráter constitucional comparado, identifica-se um norte objetivo para as formas de garantia e exercício do direito ao esporte nas Constituições de Bolívia, Cabo Verde, Colômbia, Cuba, Equador, Portugal, República Dominicana e Venezuela. Merece menção as Constituições de Guatemala e Filipinas, como anteriormente discutido, que, mesmo não prevendo o direito ao esporte são bastante informativas quanto às formas de cumprimento do dever do Estado.

Em Cuba, possivelmente a Constituição com maior institucionalidade em relação ao direito ao esporte, identifica-se um perspectiva sistêmica semelhante à apontada por Canan, Lacerda e Starepravo ${ }^{58}$ em análise a documentos internacionais. ${ }^{59}$ Nessa perspectiva, sumariamente, o Estado/ poder público deve garantir a obrigatoriedade da educação física escolar e gerar a instrução e meios/estruturas para prática esportiva da população em geral, visando contribuir para seu desenvolvimento integral. Ou seja, as pessoas devem ter acesso ao conhecimento e às vivências físicas/esportivas na educação física escolar, com intuito de que sejam incorporados como hábito, ao mesmo tempo em que precisam ser criadas condições de manutenção e incentivo a esse hábito por meio da disponibilização de condições estruturais. A Constituição da República Dominicana também aproxima-se dessa perspectiva. As Constituições de Bolívia, Cabo Verde, Colômbia, Equador, Portugal e Venezuela mantém em alguma medida o padrão, mas mostram-se menos objetivas em relação às formas de cumprimento do dever do Estado, enfatizando, cada uma, mais a educação física escolar ou mais o esporte para todos/cultura física.

No que diz respeito à natureza jurídica do direito verifica-se que o esporte enquadra-se como direito individual no que diz respeito à liberdade de prática e de associação para prática e como direito social, principalmente porque relaciona-se com um sentido lato de educação (que ultrapassa o

58 Canan, Felipe; Cabral Lacerda, Paulo José e Starepravo, Fernando Augusto, "Direito ao esporte em documentos internacionais", Congresso Brasileiro de Ciências do Esporte, XX e Congresso Internacional de Ciências do Esporte, Goiânia, Universidade Federal de Goiás, 2017, pp. 2950 e 2951.

59 Os autores analisaram vários documentos inscritos na origem institucional do direito ao esporte, dos quais destaca-se a Carta Europeia de Esporte para Todos de 1975 (Ministros Europeos Responsables del Deporte, op. cit., documento completo) e a Carta Internacional da Educação Física e do Esporte de 1978 (United Nations Educational, Scientific And Cultural Organization, International Charter of Physical Education and Sport, Paris, United Nations Educational, Scientific and Cultural Organization, 1978, documento completo).

Esta obra está bajo una Licencia Creative Commons

Atribución-NoComercial-SinDerivar 4.0 Internacional, IIJ-UNAM. 
ensino formal), sendo compreendido, dentro de uma lógica de educação permanente, como um meio de formação integral e valorização das pessoas. Além disso, em 10 (71,43\%) Constituições, o esporte é previsto no título/capítulo/seção destinado a estabelecer direitos sociais e/ou culturais, elencando-se, neste caso, no grupo dos direitos fundamentais de segunda dimensão, formado pelos direitos econômicos, sociais e culturais. Assim, independentemente ser adotado em cada Constituição como direito social ou cultural, insere-se no grupo dos direitos de segunda dimensão, genericamente tratados como direitos sociais.

Dentre as demais Constituições, a do Brasil prevê o direito ao esporte na Ordem Social, Egito nos Direitos Públicos, Equador nos Direitos de Bem Viver e México nos Direitos Humanos. Sendo assim, ao menos Brasil e Equador também estabelecem uma relação direta entre esporte e direitos sociais. Esse padrão vai ao encontro do observado por Castilla, ${ }^{60}$ Cazorla Prieto, ${ }^{61}$ Miranda ${ }^{62}$ e Pachot Zambrana, ${ }^{63}$ de que o esporte seria um novo direito social.

Em relação à fundamentalidade percebe-se que 13 (92,86\%) das Constituições, exceto o Brasil, preveem o direito ao esporte dentro de algum título/capítulo relativo à previsão de direitos, ainda que não necessariamente de direitos sociais. Isto leva a compreensão de que em tais países o direito ao esporte goza de fundamentalidade formal ou, ao menos, aproxima-se dela, vez que o funcionamento constitucional relativo a cláusulas pétreas, emendas e modificações de caráter geral não foi objeto de estudo deste artigo. Ou seja, não é possível afirmar que em todas as Constituições o esporte apresenta fundamentalidade formal porque a lógica de cada qual é diferente das demais. Mas o fato de na maioria das Constituições o direito ao esporte estar inscrito no título/capítulo destinado ao estabelecimento de direitos, que normalmente é matéria cujo retrocesso é obstaculizado sugere que tal fundamentalidade exista.

A amplitude dada ao direito por parte das Constituições que expressamente o estabelecem, normalmente a partir de um dispositivo próprio e também associado a outros direitos e/ou áreas de atuação estatal indica também fundamentalidade material. Especialmente no caso de Brasil, Egito,

\footnotetext{
60 Castilla, Karlos, op. cit., pp. 108 e 110.

61 Cazorla Prieto, Luis María, op. cit., pp. 189-192.

62 Miranda, Martinho Neves, op. cit., pp. 18-22.

63 Pachot Zambrana, Karel Luis, El derecho al deporte..., cit., pp. 14, 36-42.
} 
Nicarágua e México, que tratam o tema do direito ao esporte com bastante superficialidade a fundamentalidade material é menos visível. Canan e Starepravo $^{64}$ e Flores Fernández ${ }^{65}$ também identificam falta de concretude na Constituição brasileira e mexicana, respectivamente.

Além disso, apesar da maioria das 14 Constituições que expressamente estabelecem o direito, além de fazê-lo, apresentarem também um texto com significativa institucionalidade, o fato das 14 representarem apenas $18,67 \%$ de todas as 75 Constituições analisadas ou $28,57 \%$ das 49 que preveem o esporte sugere que em termos gerais, o direito ao esporte ainda goza de pouca fundamentalidade formal e material quando levado em conta o âmbito comparado.

\section{CONSIDERAÇÕES FINAIS}

Tendo em conta o objetivo da pesquisa verificou-se que, na perspectiva comparada, o esporte é previsto na maioria das Constituições, ao passo que o direito ao esporte é estabelecido pela minoria delas. Entretanto, das Constituições que preveem o esporte, a maioria estabelece um dever ao Estado/poder público em relação ao seu desenvolvimento.

Países dos blocos culturais ibero-americanos de língua portuguesa destacam-se no que diz respeito à complexidade e completude dos textos sobre o esporte e direito ao esporte. Este último, na realidade é estabelecido expressamente quase que exclusivamente nesses blocos.

Em relação ao direito ao esporte e em busca de oferecer subsídios para superação da carência da literatura a respeito, principalmente no que diz respeito à identificação de possibilidades concretas para seu exercício e garantia, verificou-se que não se restringe ao esporte em sentido estrito, de competição institucionalizada. Abrange também as práticas físicas/corporais em geral, sendo seu principal contexto de manifestação a educação física escolar. Em outras palavras o direito ao esporte, que na realidade é um direito às práticas físicas/corporais, comumente abarcadas pelo conceito de cultura física ou esporte para todos é especialmente garantido e exercido por meio da educação física escolar. Esta é a principal obrigação

64 Canan, Felipe e Starepravo, Fernando Augusto, "Problematizando o direito ao esporte", Congresso Sulbrasileiro de Ciências do Esporte, Criciúma, Universidade do Extremo Sul Catarinense, 2016, pp. 7-11.

65 Flores Fernández, Zitlally, “La cultura física...”, cit., pp. 187 e 188.

Esta obra está bajo una Licencia Creative Commons

Atribución-NoComercial-SinDerivar 4.0 Internacional, IIJ-UNAM. 
prestacional do poder público e outros destinatários parceiros em relação ao direito ao esporte.

Em complemento, cabe ao poder público e demais destinatários não apenas a garantia de liberdade de prática e associação para prática esportiva, mas também a disponibilização de meios para tal, em forma eminentemente de infraestrutura. Serviços esportivos para além da educação física escolar não são impossibilitados, mas não compõem o padrão principal identificado como núcleo essencial do direito ao esporte em sede constitucional.

Tem-se clareza que cada país apresenta suas peculiaridades em termos sociais, políticos, econômicos, culturais e jurídicos, somente sendo possível uma certeza a respeito da previsão do esporte e do direito ao esporte em âmbito constitucional a partir da análise da própria Constituição. Não obstante, a identificação de padrões presentes em âmbito comparado como os aqui apresentados pode contribuir para o aperfeiçoamento do ordenamento constitucional de cada país sobre a temática. Além disso, o exercício comparativo permitiu identificar quais países têm mostrado um pensamento convergente em relação ao direito ao esporte.

No caso específico identificou-se que países de língua espanhola e portuguesa têm entendido a relação entre Estado e esporte sob uma perspectiva semelhante, o que sugere a possibilidade de pensarem políticas esportivas, especialmente no que diz respeito à educação física escolar e à infraestrutura esportiva, em conjunto. Estudos futuros que busquem tecer uma comparação entre uma Constituição específica e outras, em relação ao esporte e direito ao esporte, podem agregar à compreensão da temática.

\section{REFERÊNCIAS}

BERgSGard, Nils Asle et al., Sport Policy: a comparative analysis of stability and change, Oxford, Elsevier, 2007.

CANAN, Felipe, Compreendendo o direito ao esporte no Brasil. Constitucionalização, teleologia e dogmática, tese (doutorado), Maringá, Universidade Estadual de Maringá, 2018.

CANAN, Felipe et al., "Direito ao esporte em documentos internacionais", Congresso Brasileiro de Ciências do Esporte, XX e Congresso Interna- 
cional de Ciências do esporte, Goiânia, Universidade Federal de Goiás, 2017.

CAnan, Felipe e Starepravo, Fernando Augusto, "Problematizando o direito ao esporte", Congresso Sulbrasileiro de Ciências do Esporte, Criciúma, Universidade do Extremo Sul Catarinense, 2016.

Carvalho, Weliton, “Direito Comparado-Método ou ciência?", Revista de Informação Legislativa, Brasília, ano 45, núm. 180, outubro-dezembro de 2008.

CASTILlA, Karlos, "El derecho humano a la práctica del deporte. Una propuesta desde y para la Constitución mexicana", Fair Play. Revista de Filosofia, Ética y Derecho del Deporte, Barcelona, vol. 3, núm. 2, 2015.

CAzorla Prieto, Luis María, "Deporte y Estado", Revista Aranzadi de Deporte y Entretenimiento (Monografía), Cizur Menor, 2013.

Flores FernÁndez, Zitlally, "El Contenido esencial del Derecho al Deporte. Perspectiva constitucional en Latinoamerica", Lex Social. Revista Jurídica de los Derechos Sociales, Sevilla, vol. 4, núm. 2, julio-diciembre de 2014.

FLORES FERNÁNDEZ, Zitlally, "El derecho al deporte en México", em FLORES FERNÁNDEZ, Zitlally (coord.), El derecho deportivo desde una perspectiva comparada. Los casos de España, México, Argentina, Cuba, Brasil e Mozambique, México, Editorial Flores, 2015.

FLORES FERNÁNDEZ, Zitlally, "La cultura física y la práctica del deporte en México. Un derecho social complejo", Cuestiones Constitucionales. Revista Mexicana de Derecho Constitucional, México, núm. 40, enero-junio de 2019.

GIL, Antônio Carlos, Métodos e técnicas de pesquisa social, 6a. ed., São Paulo, Atlas, 2008.

MaXimiliano, Carlos, Hermenêutica e aplicação do direito, 20a. ed., Rio de Janeiro, Forense, 2011.

Melo Filho, Álvaro, "Desporto Constitucionalizado", Revista de Informação Legislativa, Brasília, vol. 26, núm. 101, janeiro-março de 1989.

Ministros Europeos Responsables del Deporte, Carta Europea del Deporte para Todos, Universidad de Córdoba, 1975, disponible en: https://www.uco.es/deportes/media/documentacion/Carta\%20Europea\%20del\%20Deporte\%20para\%20todos.pdf, acceso em 13 set. 2018. 
MirandA, Martinho Neves, O direito no desporto, 2. ed., Rio de Janeiro, Lumen Juris, 2011.

PaChOt Zambrana, Karel Luis, El derecho al deporte, la Constitución y las normas de ordenación del deporte en Cuba, tesis (doctorado), La Habana, Universidad de Oriente, 2008.

PACHOT ZAMBRANA, Karel Luis, "El derecho constitucional al deporte en la doctrina y el derecho comparado", Cuestiones Constitucionales. Revista Mexicana de Derecho Constitucional, México, núm. 35, julio-diciembre de 2016.

SARLET, Ingo Wolfgang, A eficácia dos direitos fundamentais. Uma teoria geral dos direitos fundamentais na perspectiva constitucional, 11. ed., Porto Alegre, Livraria do Advogado, 2012.

SCHMITT DE BEM, Leonardo, "La constitucionalización del deporte”, em Millán Garrido, Antonio y Cervantes liñán, Luis (dirs.), Anuario Iberoamericano de Derecho Deportivo, ano 2, 2011, Lima, Universidad Inca Garcilaso de la Vega, 2014.

Toledo, Renata María, As políticas públicas e o direito "social” ao esporte: uma análise a partir do estado do Paraná (1995-2010), tese (doutorado), Curitiba, Universidade Federal do Paraná, 2014.

United Nations Educational, Scientific And Cultural OrganiZATION, International Charter of Physical Education and Sport, Paris, United Nations Educational, Scientific and Cultural Organization, 1978.

Fecha de recepción: 5 de abril de 2019.

Fecha de aceptación: 30 de junio de 2019.

Esta obra está bajo una Licencia Creative Commons Atribución-NoComercial-SinDerivar 4.0 Internacional, IIJ-UNAM. 